\title{
nature
}

\section{No next stop for NATO}

\section{This week's meeting of the Council of NATO makes it necessary that there should be a full-throated discussion of what happens next, which means problems for everybody.}

Not so long ago, at the end of 1987, it seemed that Europe had become a place free from nuclear weapons. Now, as this week's meeting of the Council of the North Atlantic Treaty Organisation (NATO) will have shown, Europe seems once more to have become a nuclear armed camp, or a place with ambitions in that direction. What has gone wrong, or otherwise happened, since last November's summit meeting between the United States and the Soviet Union in Washington? Several confusing and even conflicting tendencies are under way, and are likely to continue for several years. The general interest requires that they should be understood as fully as may be possible.

The most obvious of the changing ingredients of the European problem is the arms control process, now mercifully resumed. Last November's treaty (INF) requiring the removal from Europe of missiles of intermediate range is the first to have emerged from five years of negotiation at Geneva because, for technical reasons, it is the simplest that could have been reached. Since the 1950 s, when missiles were first developed to carry nuclear warheads, they have become almost conspicuous. By contrast, it is much more difficult to tell what uses are planned for other kinds of delivery systems, aircraft or battlefield howitzers, for example. It is true that President Reagan and $\mathrm{Mr}$ Gorbachev might just as well have begun with an agreement on strictly strategic weapons, on which their representatives at Geneva are even now negotiating, except that the strategic issue is unavoidably enmeshed with the US devotion to the Strategic Defense Initiative (SDI).

On that reading, the INF agreement may have been a way of patching up the previous year's failure at Reykjavik, a way of showing that arms control was not dead and (crucial from $\mathrm{Mr}$ Gorbachev's point of view) a way of discovering how the US Congress now regards bilateral arms control agreements. Reagan and Gorbachev may have been willing to overlook a few gaps in the document they signed, such as the ambiguous status of British and French nuclear weapons, in the expectation that more agreements would soon follow. Where they appear to have miscalculated is their belief that others would be prepared to put their anxieties on ice until there is another draft treaty from Geneva.

In the event, as this week's meeting will have shown, there are two quite distinct tendencies within Europe proper. West Germany, filled with anxiety at the prospect of INF in advance of last November's summit, but having seen Soviet missiles being dismantled and carted away from Eastern Europe in the past few weeks, does not now relish the notion that short-range nuclear weapons (not covered by INF) might be modernized. (Those who guess that West Germany's motives centre on fears that West Germany would be the likely target for these weapons reckon without the glittering attraction of Ostpolitik.) At the same time, Britain and France, closer together on this issue than at any time since 1954, appear determined to keep their independent nuclear forces, in reality substitutes for some of the missiles being dismantled under INF, strong - if not to make them stronger. Finally, the complex political animal which is the United States, having agreed to withdraw nuclear missiles from Europe, is plainly wondering whether it should continue to keep
300,000 members of its armed services there.

All this is understandable, and should also have been predictable. The only course that NATO can reasonably hope to follow is to keep to something like the status quo at least until the next instalment of the summit meetings, possibly in April. At that stage, if the planned agreement on strategic arms is to materialize, it is inevitable that British and French nuclear weapons will somehow have to be counted (as, implicitly, they were in the SALT II agreement of 1978). The snag, for France and, increasingly, for Britain is that these independent nuclear forces are justified by the Gallois doctrine of the 1950 s that the destructive power of a smaller power's nuclear forces will suffice as a deterrent to greater powers if they match its own value to an adversary as a prize. Although the British Prime Minister, Mrs Margaret Thatcher, has said that British nuclear forces could be negotiable if there were general progress towards arms control (the French have said nothing), it is inevitable that the British nuclear forces will seem more endearing to those who pay for them as those circumstances come closer.

That is why the best strategy, for Britain and France in one camp, West Germany in another but also for the United States, conscious for the first time that it is overstretched by its commitments, is to plan for yet another series of arms control negotiations with the Soviet Union, dealing with European security. That is the only setting in which understanding could rationally be reached on the deployment of short-range nuclear weapons as well as on the British and French strategic nuclear forces. Both sides have much to gain from such an accommodation, which would at least be easier to define than will be the search for a trade-off between strategic arms and SDI. The stumbling block is the old-fashioned truth that an agreement on European security will require an understanding on relations between Eastern European states and the rest of Europe. That is evidently a more serious obstacle for the Soviet Union than for, say, West Germany.

\section{Electric company sale}

\section{The British government has a bad recipe for} selling a public monopoly.

THE British government has at least one thing to its credit: it has already explored more ways of selling public monopolies to the private sector than any other government. The now familiar problem is that of balancing the proceeds (which help to swell the Treasury) against the public interest (which requires that newly privatized companies should efficiently sell their services cheaply). Evidently the hope is that some future formula will prove to be a huge success, capable of being replicated indefinitely. But what if the circle cannot be squared, and if there is no basis on which public monopolies made private can be structured in such a way that they are inherently efficient and cheap? In such a case, the British will run out of nationalized industries before the search for the ideal formula is complete.

That is the worry that should be keeping Mr Cecil Parkinson, now the Secretary of State for Energy in the British government, 